\title{
THE DISINTERESTED PERSON: AN ALTERNATIVE APPROACH TO SHAREHOLDER DERIVATIVE LITIGATION
}

\author{
Joel Seligman*
}

\section{INTRODUCTION}

With the increased use of alternative dispute resolution techniques in corporate and securities law, ${ }^{1}$ we have reached the point Justice Frankfurter addressed in SEC v. Chenery Corp., ${ }^{2}$ where we might inquire: "But to say that an alternative dispute resolution technique is appropriate only begins the analysis; it gives direction to further inquiry, which alternative dispute resolution technique is appropriate? How should it be structured?"

I urge that we would do well to study Continental civil procedure, in particular its concept of an investigative judge, for suggestions of how to refine our existing alternative dispute resolution procedures in shareholder derivative litigation. Professor Langbein, for example, in an enthusiastic description of the former German method of civil procedure ("German model"), has emphasized the advantages of judicial fact gathering in streamlining discovery, selection of expert witnesses, and encouragement of settlements. Langbein suggests that the German model is preferable to "[o]ur lawyer-dominated system of civil procedure," which he characterizes as "often . . . criticized both for its incentives to distort evidence and for the expense and complexity of its modes of discovery and trial."3 Specifically,

Copyright $(1992$ by Law and Contemporary Problems

- Professor of Law, University of Michigan Law School.

Let me express my gratitude for comments concerning an earlier draft of this article to Professors Alfred F. Conard, John C. Coffee, Jr., James D. Cox, Merritt Fox, Richard Friedman, Harvey Goldschmid, Samuel R. Gross, John H. Langbein, Richard O. Lempert, and Roberta Romano, as well as Cyril Moscow.

1. See discussion of special litigation committee in shareholder derivative litigation in text accompanying notes 12 and 29; for a comparison of arbitration in securities broker-customer disputes, see generally Shearson/American Express, Inc. v McMahon, 482 US 220 (1987); Center for Public Resources, Model ADR Procedures: $A D R$ in Securities Disputes (Center for Pub Res, 1991).

2. 318 US 80, 85-86 (1943).

3. John H. Langbein, The German Advantage in Civil Procedure, 52 U Chi L Rev 823, 823 (1985). For a more skeptical view, compare Samuel R. Gross, The American Advantage: The Value of Inefficient Litigation, 85 Mich L Rev 734 (1985).

In 1977 Germany enacted sweeping civil procedure reforms, making its system more similar to the Anglo-American method. For a comparison of the former German system (referred to in this article) with its modern counterpart, see Arthur T. von Mehren, Some Comparative Reflections on First 
Langbein emphasizes two fundamental differences between German and Anglo-American civil procedures:

First, the court rather than the parties' lawyers takes the main responsibility for gathering and sifting evidence, although the lawyers exercise a watchful eye over the court's work. Second, there is no distinction between pretrial and trial, between discovering evidence and presenting it. Trial is not a single continuous event. Rather, the court gathers and evaluates evidence over a series of hearings, as many as the circumstances require. ${ }^{4}$

Recently I had the opportunity to apply a somewhat similar procedure in a shareholder derivative suit. In 1989, Michigan amended its Business Corporation Act to allow a court, under specified circumstances, to appoint a "disinterested person" to perform fact-gathering functions similar to those of a German investigative judge. ${ }^{5}$ In 1991 I was appointed to be the disinterested person in derivative litigation involving the Rospatch Corporation. ${ }^{6}$ This experience persuaded me that in shareholder derivative litigation certain features of the Continental civil procedure model can be combined profitably with the more adversarial United States model through the medium of a disinterested person. Compared to litigation and the special litigation committee, the disinterested person approach may offer the following significant advantages: reduction of litigation costs, increased procedural fairness, and greater protection of shareholders.

My argument contains two parts. First I will describe the imperfections in the current models of shareholder dispute resolution that suggest a need for a new alterative. Second I will describe advantages that the disinterested person procedure may offer.

\section{The Dilemma of the Derivative Action}

The shareholder derivative action's essential purpose is to compensate shareholders for losses suffered as a result of officer or director violations of the duties of due care or loyalty. Shareholder derivative actions offer the incidental benefits of deterring some forms of corporate cupidity, restraining some wastes of assets, and accumulating some of the winnings from litigation

Instance Civil Procedure: Recent Reforms in German Civil Procedure and in the Federal Rules, 63 Notre Dame L Rev 609, 614-22 (1988).

4. Langbein, $52 \mathrm{U}$ Chi $\mathrm{L}$ Rev at 826 (cited in note 3).

5. Mich Comp Laws Ann $\S \S 450.1491 \mathrm{a}(\mathrm{c}), .1495$ (West 1990); see generally Stephen $H$. Schulman, Cyril Moscow \& Margo R. Lesser, Michigan Corporation Law ڤ Practice $\$$ 4.26, 5.3 (Prentice Hall Law \& Business, 1990).

6. The Jerry Atcovitz $v$ J. Grant Beadle, et al, derivative litigation was part of a consolidated proceeding styled In re Rospatch Securities Litigation, 760 F Supp 1239 (WD Mich 1991).

On August 1, 1991, I filed a 339-page report, the recommendation of which was adopted by the court in Jerry Atcovitz v J. Grant Beadle, et al, No 1:90-CV-807 (WD Mich 1991). This report was longer than I assume usually will be necessary because I concluded both that (1) certain of the plaintiffs' allegations were meritorious, but (2) the derivative action should be dismissed because each of the meritorious allegations was also alleged in parallel direct federal securities actions. To ensure appropriate recovery to the corporation, I recommended that the court apportion damages or supervise settlement amounts in such a way that the individual derivative action defendants would bear an appropriate share of any recovery in the direct actions. 
or settlements to the corporation for the equitable protection of creditors as well as shareholders. ${ }^{7}$ These are significant advantages.

But these virtues are achieved at a price, since a sizable share of derivative litigation winnings go, not to the corporation, but to the plaintiffs' lawyers, feeding the suspicion that the derivative action's true purpose is to enrich the plaintiffs' bar. This is not a novel complaint, but merely echoes a critique that can be directed at almost any aspect of plaintiffs' litigation ranging from malpractice actions to environmental litigation. Alone, the notion that plaintiffs' attorneys do well for themselves by doing good for others should not be decisive. ${ }^{8}$

Three factors, however, combine to make this traditional critique more significant in the case of the derivative action. First, the shareholder derivative action is sometimes unnecessary. For example, when material misrepresentations or omissions can be alleged, they can be addressed through a direct federal securities action rather than a derivative suit. In these cases, the derivative suit's deterrent value has been reduced because of the increased use during the last three decades of the federal securities law antifraud remedies. The winnings from these claims redound to the same outside shareholders who often are the indirect victors in derivative litigation.

Second, both derivative and direct actions have become increasingly complex in the last few decades. Typically, federal securities law claims today are joined to pendent state fraud actions, and often to civil RICO and state consumer claims as well. This broad joinder means that discovery in a shareholder derivative action typically begins with a very wide net capable of enveloping documents of the corporation, its board of directors, its chief officers, its outside attorney, its outside auditor, and often its subsidiary or affiliated corporations. This blunderbuss discovery gives a greater ring of truth to the old critique of the derivative claim, that it is extraordinarily expensive and disruptive. When this critique is combined with additional considerations of the increased hourly costs for attorneys, accountants, and expert witnesses, the assertion that the derivative litigation can be "ruinous" to a small- or medium-sized business cannot be entirely dismissed.

Third, there is a factor that verges on the historical accident: the development of the special litigation committee. In the mid-1970s, several hundred U.S. corporations were found to have paid "questionable payments" or bribes through their overseas operations. Some of these corporations' officers were also sued in derivative claims. But these were somewhat unusual derivative suits. Although corporate officers may have committed legal or moral wrongs, they could often claim that they did so to enrich their firms, not to mulct them. ${ }^{9}$

7. For a recent review of the relevant literature, see Roberta Romano, The Shareholder Suit: Litigation without Foundation?, 7 J L Econ \& Org 55 (1991).

8. Compare John C. Coffee, Jr., The Unfaithful Champion: The Plaintiff as Monitor in Shareholder Litigation, 48 L \& Contemp Probs 5 (Summer 1985).

9. See, for example, Louis Loss \& Joel Seligman, 3 Securities Regulation 660-61 (Little Brown, 3d ed 1989). 
The law's response to these events was revolutionary. To limit the derivative claim, a new technique, often called "the special litigation committee," arose. ${ }^{10}$ The purpose, expressed or implied, of the special litigation committee is to terminate derivative claims.

This is not to say that the special litigation committee is without merits. It has the practical virtue of being far less expensive and disruptive than the older derivative claim. On occasion it has also led to some changes in corporate personnel or in corporate practice. ${ }^{11}$

There is another less subtle advantage of the special litigation committee. In the past a court that believed that a shareholder derivative action was lacking in merit often had two clumsy alternatives: either it could grant a defendant's motion to dismiss summarily on the basis of the complaint, essentially without discovery, or it could deny the motion, allow full discovery, and typically allow the action to proceed to trial. From the court's point of view, the special litigation committee had the advantage of ensuring that there would be some internal discovery and some internal review of relevant documents and relevant personnel before a climactic decision was made.

Moreover, in administering shareholder derivative actions, the court could create incentives to attempt to make the process fairer. It could require that there could be no adoption of the special litigation committee's recommendation to dismiss unless the court was satisfied that all material evidence had been discovered. It could require the special litigation committee to meet with plaintiffs' attorneys or witnesses recommended by the plaintiffs to ensure that part of the adversarial process was integrated into the special litigation committee investigation. The court could take into account efforts by the corporation to cleanse itself voluntarily. The court could be more reluctant to grant dismissal if the personnel on the special litigation committee appeared to be biased or the factual or legal analysis too crude or too simple. These techniques would give the court supervising the special litigation committee some opportunities to improve the process while simultaneously reducing the derivative action's overall cost and disruption to the corporation. ${ }^{12}$

10. See, for example, John C. Coffee \& Donald E. Schwartz, The Survival of the Derivative Suit: An Evaluation and a Proposal for Legislative Reform, 81 Colum L Rev 261, 272-74 (1981); James D. Cox, Searching for the Corporation's Voice in Derivative Suit Litigation: A Critique of Zapata and the ALI Project, 1982 Duke L J 959, 964-72; George W. Dent, Jr., The Power of Directors to Terminate Shareholder Litigation: The Death of the Derivative Suit?, 75 Nw U L Rev 96, 105-09 (1980).

11. These changes can be indirect. The initiation of the shareholder derivative claim and the subsequent appointment of a special litigation committee can prompt the Securities and Exchange Commission or relevant state securities officials to investigate the corporation. The filing of a shareholder derivative claim might also have a direct and significant impact on the price of the relevant corporation's stock. The key is that while the special litigation committee might directly have been a device to dismiss derivative claims, indirectly it often coexists with other pressure for reform.

12. See text accompanying notes 1 and 29 .

Judicial ability to create incentives to make the process fairer, however, essentially is limited to cases where a majority of the board is tainted by a lack of independence, and facts to this effect have been alleged with sufficient particularity. See Aronson v Lewis, 473 A2d 805 (Del 1984); Grobow v Perot, 539 A2d 180 (Del 1988). 
Admirable as these techniques may be, they are not equivalent to the advantages of the adversarial system in conventional shareholder derivative litigation. Crucial witnesses, typically including relevant corporation officers and directors, are interviewed only by the special litigation committee or its counsel. Often the counsel is a distinguished law firm with a long record of defending shareholder derivative litigation. This counsel usually has had considerable courtroom experience and is well practiced in cross examination. Nonetheless, such counsel does not have the same incentive to probe or to question a witness' veracity or lack of memory as an adversarial attorney would. Moreover, the penalties imposed upon a witness for memory lapse or fabrication are considerably less than in a courtroom: the witnesses often are not under oath; often their testimony is not transcribed; and usually they are not subject to such penalties as perjury or even the courtroom judge's moral suasion. Hence, claims that might not seem persuasive to a jury or other fact finder in a courtroom might seem persuasive to a special litigation committee's counsel, who is most psychologically prepared to accept them.

There is also the question of whether a special litigation committee's counsel has a sufficient evidentiary basis to question or doubt witnesses. To be sure, a corporation will invariably open up its relevant files and records, and provide the counsel with all documents from which a sufficient evidentiary basis can be developed. But merely having documents is not enough. It is more important to understand them fully. The special litigation committee's counsel may miss or ignore disclosures or appropriate inferences that could be drawn from these documents. This might occur, not because of bad faith or lassitude, but simply because of the lesser incentive and time that the committee's counsel has to find damning or incriminating evidence than the typical plaintiffs' attorney has.

The choice between the traditional shareholder derivative lawsuit and the newer special litigation committee approach to derivative litigation is not, ultimately, a Manichean choice between good and evil. Shareholder derivative litigation is unquestionably more expensive and disruptive to the corporation, but it is also more likely to discover and prove that officers or directors have committed legal wrongs. The special litigation committee, in contrast, particularly when cabined by appropriate judicial procedures, is generally less expensive, less disruptive to the corporation, and often less likely to discover that corporate officers or directors have committed actionable wrong. The choice is essentially between an expensive adversarial process and a less expensive nonadversarial process.

To present only this stark choice, however, is unrealistic. The shareholder litigation device, like federal securities law direct actions, does not exist in a vacuum. It is part of a litigation process that more often than not results in settlements. ${ }^{13}$ From this point of view, as the cost and capacity for disruption

13. See, for example, William E. Haudek, The Settlement and Dismissal of Stockholders' Actions-Part II: The Settlement, 23 Sw L J 765 (1969); Janet C. Alexander, Do the Merits Matter? A Study of Settlements 
of shareholder derivative litigation increases, the plaintiff's bargaining leverage expands substantially. On the other hand, the increased use of the special litigation committee expands the defendant's bargaining leverage, since the committee will usually recommend the action's dismissal, terminating the plaintiffs' attorneys' right to a fee. Increasingly, the plaintiffs' bar might face a Hobson's choice: either settle the litigation, typically receiving fees for the plaintiffs' attorneys but relatively little for the actual plaintiffs in the derivative litigation, or suffer the overwhelming probability of defeat through dismissal of the shareholder derivative claim.

In response, many shareholders are increasingly litigating their derivative claims simultaneously with separate federal securities claims. When this occurs, the defendants may succeed in choking off the shareholders' derivative claim through the special litigation committee, but they cannot prevent the plaintiffs from going forward with the direct federal securities law claim.

In this way, shareholder derivative litigation may appear to achieve a certain "rough justice." The claim itself may be subject to the special litigation committee's usual recommendation of dismissal. At the same time, however, the plaintiffs' ability to wrest a substantial settlement (including a substantial attorney's fee) is increased when the claim is litigated simultaneously with a federal securities law claim and other pendent claims. Thus, in a crude way, the law continues to ensure that derivative claims will be filed and that corporations will pay some penalties for the misdeeds of their officers and directors.

The big loser may well be the corporate shareholder. While nominally the derivative litigation is in the shareholder's name, with recovery to go to the corporation for the shareholder's protection, in reality the recovery in shareholder derivative litigation typically goes, in large measure, to the plaintiffs' bar rather than to the corporation. These effects are less substantial in larger business corporations, where the practical significance of litigation compared to the corporation's income or assets is proportionately smaller. But in the medium-sized corporation in particular, the shareholder derivative claim, far from being a panacea for the protection of stockholders' interests, can be a disaster; the transaction costs of a clumsy process may dwarf the possible recovery.

\section{III}

\section{The Disinterested Person Alternative}

The Michigan Business Corporation Act's "disinterested person" is an attractive alternative to both litigation and the special litigation committee in shareholder derivative suits. The Act defines a "disinterested person" as "a

in Securities Class Actions, 43 Stan L Rev 497, 498 (1991) ("Although trial is our paradigm of how civil litigation resolves disputes, in reality only a tiny fraction of litigated cases-perhaps five percent or less-are actually tried to judgment." (citations omitted)). 
person who is not a party to a derivative proceeding, or a person who is a party if the corporation demonstrates that the claim asserted against the person is frivolous or insubstantial." 14 The Act also provides:

The court shall dismiss a derivative proceeding if, on motion by the corporation, the court finds that [one or more disinterested persons appointed by the court] has made a determination in good faith after conducting a reasonable investigation upon which its conclusions are based that the maintenance of the derivative proceeding is not in the best interests of the corporation .... If the determination is made [by one or more disinterested persons], the plaintiff shall have the burden of proving that the determination was not made in good faith or that the investigation was not reasonable. ${ }^{15}$

Neither the Michigan statute nor similar statutes adopted in other states define the terms "best interests of the corporation" or "reasonable investigation." 16

While the Michigan statute is not a jewel of definitional precision, the core concept implicit in the role of the disinterested person is reasonably clear. The disinterested person, rather than being a corporate employee or agent, ${ }^{17}$

14. Mich Comp Laws Ann $\$ 450.1491 \mathrm{a}(\mathrm{c})$. There is some risk with judicial appointment of a disinterested person that "friends of the judge" might be appointed. The relevant corporation can totally obviate this risk, when its counsel believes it is real, by not seeking appointment of a disinterested person and simply proceeding to summary judgment. This risk is also reduced to the extent that the report of the disinterested person is subject to some appellate review. The risk could be further reduced by statutory or judicial procedures allowing the parties to challenge a list of potential disinterested persons on grounds of competence, among others. In any event, "let not the better be the enemy of the good." The disinterested person, warts and all, is more likely to be a neutral fact finder than the special litigation committee.

15. Id $\$ 450.1495$

16. See, for example, Alaska Stat $\S 10.06 .435$ (1989); Fla Stat Ann $\$ 607.07401$ (West Supp 1991); Ind Code Ann $\S 23-1-32-4$ (West 1989); ND Cent Code $\$ 10-19.1-49$ (1989) (requiring written report of its determinations to the board); Va Code Ann $\$ 13.1-672$ (Michie Supp 1992); compare Committee on Corporate Laws, Changes in the Model Business Corporation Act-Amendments Pertaining to Derivative Proceedings, 45 Bus Law 1241, 1246-53 (1990) (the "inquiry" concept in the Model Business Corporation Act's $\$ 7.44$ provides an analogy to the Michigan reasonable investigation concept). Both the Revised Model Business Corporation Act, see $\$ 7.44(f)$, and The American Law Institute, Principles of Corporate Governance: Analysis and Recommendations $\$ 7.12$ (Tent Draft No 11 April 25, 1991) ("ALI Tent Draft No 11), also include the disinterested person procedure, albeit using slightly different vocabulary.

There are other questions that could be addressed, such as:

(1) How should a disinterested person be selected? Should the parties have any role in his or her selection?

(2) Should nonattorney disinterested persons be required to obtain an attorney's legal analysis?

(3) Who should bear the cost of the disinterested person review? Should this cost invariably be imposed on the corporation or should a court have discretion to apportion part of the cost to the plaintiffs or the defendants?

17. The Michigan statute permits a disinterested person to be a party to a derivative proceeding "if the corporation demonstrates that the claim asserted against the person is frivolous or insubstantial." Mich Comp Laws Ann $\$ 450.149$ la. On the other hand, $\$ 450.1495$ distinguishes a "disinterested person" from a "disinterested director." Given the rare involvement of a disinterested person in a corporation's affairs, a better-phrased standard would require the disinterested person to be totally uninvolved with a corporation for at least a minimum period before appointment. 
should be a neutral fact finder similar to a trial court judge, ${ }^{18}$ a Bankruptcy Code examiner, ${ }^{19}$ or the federal courts' Master. ${ }^{20}$

This aspect of the disinterested person procedure is significant. One much-stressed criticism of the special litigation committee is that directors evaluating other directors will not be able to reach a disinterested judgment. This concern has been variously expressed as " 'there but for the grace of God go I' empathy,"21 "the danger of allowing the board of directors to appoint a few 'good ol' boys' as a special litigation committee and to be accordingly whitewashed," 22 or the "structural bias" of a special litigation committee whose members were selected by defendant-directors. ${ }^{23}$ However phrased, the problem posed by such directors on a special litigation committee is an obvious one. As one North Carolina court observed, "not one committee, in all these instances, has decided to proceed with suit."24

Another benefit of this system is that by appointing a disinterested person to evaluate a plaintiff's derivative action claims, courts are likely to get an evaluation equivalent to a conventional "business judgment." 25 Such an evaluation essentially involves the same type of disinterested or arm's length

18. See, for example, Ward v Village of Monroeville, 409 US 57, 60 (1972) (characterizing the role of the judiciary as "hold[ing] the balance, nice, clear and true between the state and the accused").

19. See, for example, Loss \& Seligman, 4 Securities Regulation at 1657-67 (cited in note 9).

20. FRCP 53. See Charles A. Wright, Arthur R. Miller \& Mary K. Kane, 9 Federal Practice and Procedure \$§ 2601-2615 (West, 2d ed 1983).

21. Zapata Corp. $v$ Maldonado, 430 A2d 779, 787 (Del 1981).

22. Abella v Universal Leaf Tobacco Co., Inc., 546 F Supp 795, 799 (ED Va 1982).

23. See Miller $v$ Register $\mathcal{E}$ Tribune Syndicate, Inc., 336 NW2d 709, 716-18 (Iowa 1983); Hasan $v$ Clevetrust Realty Investors, 729 F2d 372, 376-77 (6th Cir 1984); but see Aronson, 473 A2d at 815 n8; Peller $v$ The Southern Co., 707 F Supp 525, 527-28 (ND Ga 1988) (citing cases), aff'd, 911 F2d 1532 (1 1 th Cir 1990); Dent, $75 \mathrm{Nw}$ U L Rev at 111 (cited in note 10) ("When charges are leveled against a majority of the directors, the pressures on even nonimplicated directors are so great as to justify a conclusive presumption that they cannot independently investigate and weigh the facts and reach a conclusion that is in the best interest of the corporation."); see generally id at 111-17; Coffee \& Schwartz, 81 Colum L Rev at 283 (cited in note 10); James D. Cox \& Harry L. Munsinger, Bias in the Boardroom: Psychological Foundations and Legal Implications of Corporate Cohesion, $48 \mathrm{~L} \&$ Contemp Probs 83 (Summer 1985).

24. Alford $v$ Shaw, 72 NC App 537, 548, 324 SE2d 878, 886 (1985), modified, 320 NC 465, 358 SE2d 323 (1987); see also Cox, 1982 Duke L J at 963 (cited in note 10) ("[A]lthough there have been more than a score of special litigation cases to date, in all but one the committee concluded that the suit in question was not in the corporation's best interest." (citations omitted)). Professor Deborah A. DeMott, in her work Shareholder Derivative Actions: Law and Practice 98 (Callaghan, 1987)(1991 Cum Supp), cites only one case in which a litigation committee recommended that the corporation sue former officers, Kaplan v Peat, Marwick, Mitchell E Co., 529 A2d 254, 256 (Del Ch 1987). However, none of these authorities addresses how often litigation committee reports have inspired or recommended settlements.

25. Compare Auerbach $v$ Bennett, 47 NY2d 619, 630-31, 393 NE2d 1000-01 (1979); Joy v North, 692 F2d 880, 885-87 (2d Cir 1982); In re Consumers Power Co. Derivative Litig., 132 FRD 455, 469, 483 (ED Mich 1990).

Under existing law, a disinterested person's (1) fact finding and (2) legal analysis and conclusions are judicially reviewed under a business judgment standard. It is possible for a disinterested person to find facts in a legally unassailable way but misinterpret or misapply the law.

I do not address in this article other questions that can be posed concerning judicial review of a disinterested person's or special litigation committee's report, notably including whether the standard of review should vary depending on the type of alleged wrong. For example, it can be argued that there should be closer judicial scrutiny of self-dealing claims than of duty of care claims. Compare ALI Tent Draft No 11 at $\S 7.10(b)$ (cited in note 16). 
cost-benefit analysis that a board of directors might undertake before deciding whether to build a new plant or introduce a new product. ${ }^{26}$ In contrast, courts in recent years have heard the complaint that special litigation committees were not sufficiently independent ${ }^{27}$ or that their legal analysis was biased. ${ }^{28}$

Though the disinterested person procedure can be undertaken for less cost and entails less disruption than the special litigation committee, ${ }^{29}$ it is also subject to the same type of procedural restrictions as the special litigation committee. Significantly, however, the disinterested person can also perform a role like that of the German investigative judge, helping to promote settlements as the fact-gathering process unfolds. In Langbein's view of the German model,

the tradition is strong that the court promotes compromise. The judge who gathers the facts soon knows the case as well as the litigants do, and he concentrates each subsequent increment of fact-gathering on the most important issues still unresolved. As the case progresses the judge discusses it with the litigants, sometimes indicating provisional views of the likely outcome. ${ }^{30}$

The key is that the disinterested person procedure begins from a quite different express or implied premise than the special litigation committee procedure. While the appointment of a special litigation committee usually results in a recommendation to dismiss derivative litigation, the disinterested person procedure is more neutral and should provide a good faith, intellectually honest effort to evaluate the merits of a derivative claim. The disinterested person should not invariably conclude that derivative claims are meritless. The disinterested person should evaluate claims on the merits for the purpose of determining whether or not a claim is in the best interests of the corporation.

This change in purpose should lead to important refinements in what is meant by the pivotal statutory terms "best interests of the corporation" and "reasonable investigation."

26. As Justice Brandeis wrote over seven decades ago in the context of a shareholder derivative claim against an unaffiliated outside party:

Whether or not a corporation shall seek to enforce in the courts a cause of action for damages is, like other business questions, ordinarily a matter of internal management and is left to the discretion of the directors, in the absence of instruction by vote of the stockholders. Courts interfere seldom to control such discretion intra vires the corporation, except where the directors are guilty of misconduct equivalent to a breach of trust, or where they stand in a dual relation which prevents an unprejudiced exercise of judgment . . . .

United Copper Sec. Co. v Amalgamated Copper Co., 244 US 261, 263-64 (1917). Compare Joy v North, 692 F2d at 887; Genzer v Cunningham, 498 F Supp 682, 688 (ED Mich 1980) ("where . . there is no allegation of personal gain by directors").

27. See notes $21-23$ and accompanying text.

28. See, for example, Lewis v Fuqua, 502 A2d 962 (Del Ch 1985).

29. See text accompanying notes 1 and 12 .

30. Langbein, $52 \mathrm{U}$ Chi L Rev at 831-32 (cited in note 3). 


\section{A. Best Interests of the Corporation}

The Michigan statute creating the disinterested person procedure does not define the phrase "best interests of the corporation." Although several special litigation committee cases have defined this term, the typical formulation is vague and of little operational help. ${ }^{31}$ For example, in Auerbach $v$. Bennett, the New York Court of Appeals stated that the concept involves "the weighing and balancing of legal, ethical, commercial, promotional, public relations, fiscal and other factors familiar to the resolution of many if not most corporate problems." 32

A more useful starting point appears in Joy $v$. North ${ }^{33}$ where Judge Winter considers "the best interests of the corporation" while discussing judicial review of a special litigation committee's recommendations:

The function of the court's review is to determine the balance of probabilities as to likely future benefit to the corporation, not to render a decision on the merits, fashion the appropriate legal principles or resolve issues of credibility .... The court's function is thus not unlike a lawyer's determining what a case is "worth" for purposes of settlement.

Where the court determines that the likely recoverable damages discounted by the probability of a finding of liability are less than the costs to the corporation in continuing the action, it should dismiss the case. The costs which may properly be taken into account are attorney's fees and other out-of-pocket expenses related to the litigation and time spent by corporate personnel preparing for and participating in the trial. ...

Judicial scrutiny of special litigation committee recommendations should thus be limited to a comparison of the direct costs imposed upon the corporation by the litigation with the potential benefits. ${ }^{34}$

There are several aspects of this formulation that are attractive. Judge Winter emphasizes, as most other judges have not, the inherently preliminary nature of the work of a special litigation committee or disinterested person. Unlike a court, a disinterested person must attempt to predict a likely outcome before full discovery. Even if a disinterested person were able to discover all or virtually all of the relevant documents that might be introduced at a subsequent trial, it is highly unlikely that a disinterested person would subject all possible witnesses to the same type of deposition process as used in the pretrial stages of an adversarial litigation. In essence a disinterested person is asked to make a prediction based on some, but not all, of the information that would be available to a court if the matter were litigated.

A disinterested person, at most, can also only guess how a jury or other fact finder will resolve issues of credibility or disputed testimony. While an investigation that involves interviewing many potential witnesses may give a

31. See, for example, Auerbach, 47 NY2d at 633, 393 NE2d at 1002; Zapata Corp., 430 A2d at 788 (similar); Gaines v Haughton, 645 F2d 761, 767-68 n11 (9th Cir 1981); Abella, 546 F Supp at $801 \mathrm{n} 13$. See also Cox, 1982 Duke L J at 985-89 (cited in note 10); Robert K. Payson, Michael D. Goldman \& Gregory A. Inskip, After Maldonado - The Role of the Special Litigation Committee in the Investigation and Dismissal of Derivative Suits, 37 Bus Law 1199, 1206-07 (1982).

32. 47 NY2d at 633 .

33. 692 F2d at 880 (2d Cir 1982).

34. Id at 892 . 
disinterested person confidence that the judge or jury is likely to find facts in a particular way, such predictions must be made with appropriate humility. Juries sometimes surprise the most experienced litigator. Moreover, there may be a greater likelihood of surprise at this stage of a disinterested person (or special litigation committee) investigation than at a trial, given the incompleteness of evidence available to the disinterested person, the unlikelihood that a disinterested person will hear the equivalent to the advocates' opening and closing statements, and the inability of a disinterested person to see how the fact finder reacts to testimony or evidence.

1. Refining Joy v. North: Predicting Litigation Outcomes. For these and similar reasons, one important refinement of Joy $v$. North would involve the use of crude variables in predicting the probable outcome of a trial. Few assertions are less reasonable than a prediction that a given litigation outcome is ninetynine percent (or whatever precise number) certain. No disinterested person or special litigation committee should pretend to have that level of confidence. Far preferable is the accounting profession's approach to predicting "loss contingencies," including litigation outcomes, before one or more future events occur or fail to occur. ${ }^{35}$ When a loss contingency exists, according to Financial Accounting Standards Board Statement No. 5, the likelihood that a future event will confirm the loss can range from "probable" (meaning "likely to occur") to "reasonably possible" ("more than remote but less than likely") to "remote" ("the chance of the future event or events occurring is slight"). Because corporate and securities law attorneys are involved in responding to auditors' requests concerning pending litigation, ${ }^{36}$ this is a type of approach with which the relevant segment of the bar is already familiar. ${ }^{37}$

In the context of a disinterested person or special litigation committee investigation, crude predictions of likely outcomes are important for another reason. There have been several suggestions that a calculation of the best interests of a corporation should involve more than a litigation cost-benefit analysis. ${ }^{38}$ In some circumstances these alternatives to the basic Joy $v$. North standard may be appropriate. Normally, however, it is preferable to subsume

35. Financial Accounting Standards Board, Statement of Financial Accounting Standards No. 5 ๆ 33 39 (1975) specifically concerns litigation.

36. See, for example, ABA, Statement of Policy Regarding Lawyers' Responses to Auditors' Requests for Information, 31 Bus Law 1709 (1976); James J. Fuld, Lawyers' Responses to Auditors-Some Practical Aspects, 44 Bus Law 159 (1988).

37. As two leading commentators have observed, "Although the FASB provided these definitions, SFAS 5 did not include specific qualitative probabilities. Therefore, a good deal of judgment is necessary in applying them." Robert S. Kay \& D. Gerald Searfoss, Handbook of Accounting and Auditing 26-27 (Warren, Gorham \& Lamont, 2d ed 1989). Presumably they meant to refer to quantitative, not qualitative, probabilities.

38. Among other variants to the Joy $v$ North standard are the following:

(1) The American Law Institute, Principles of Corporate Governance: Analysis and Recommendations $\$ 7.10(\mathrm{~b})(2)(\mathrm{A})$ (cited in note 16 ), would give special weight to improper benefits secured by defendants "[a]s the result of a knowing and material misrepresentation or omission or other fraudulent act" in evaluating the benefits to a corporation. "The policy judgment . . . is that the long term interests of shareholders will be better served if the derivative action retains a credible deterrent threat over this range of cases . . . American Law Institute, Principles of Corporate 
these other factors in a crude litigation cost-benefit analysis. Any effort to calculate simultaneously both a litigation cost-benefit analysis and a value or weight for such factors as the deterrent value of derivative litigation or the impact of disruption on key corporate personnel will be necessarily speculative and imprecise.

\section{Refining Joy v. North: Application to Complex Claims. A second refinement} of the Joy $v$. North standard may be appropriate for complex derivative claims. None of the special litigation committee cases to date has addressed the need for any form of intermediate process. The expectation is simply that the committee will file a report at the conclusion of its investigation.

In my experience as a disinterested person analyzing the derivative claims in In re Rospatch Securities Litigation, ${ }^{39}$ which alleged twenty-two separate possible causes of action, I found that the only practical way I could make the Joy $v$. North standard operational was by pursuing a three-tiered investigation.

First, after the plaintiffs had submitted all documents that they believed supported their complaint and I had received all requested documents from the nominal defendant, Rospatch, I concluded that thirteen possible causes of action alleged in the plaintiffs' complaint did not warrant further investigation. These conclusions were either based on the lack of sufficient

Governance: Analysis and Recommendations $\S 7.08$ at 151 (ALI Tent Draft No 8, April 15, 1988) (“ALI Tent Draft No 8"').

I am skeptical that improper benefits secured by defendants can be meaningfully distinguished from other types of injury. For example, such an improper benefit might include a bonus received by a corporation's senior managers as a result of a fraudulent overstatement of the corporation's earnings. Why should this type of case be considered more serious than a fraudulent overstatement of a corporation's earnings when the executive did not receive a bonus? In both cases the outside shareholders are defrauded. In both cases the law should be concerned with deterring fraud. Moreover, the supposed improper benefit, the bonus, may be of less consequence to the senior executives than the greater job security occasioned by the higher apparent earnings.

(2) In limited circumstances Judge Winter would take into account two indirect types of cost: First, the impact of distraction of key personnel by continued litigation, and, second, potential lost profits which may result from the publicity of a trial. Joy $v$ North, 692 F2d at 892-93. When there are simultaneous direct and derivative actions, the significance of these types of costs is substantially reduced. Key personnel will be distracted and corporate profits threatened by the direct action regardless of whether the derivative action proceeds. Compare Jerold S. Solovy, Barry Levenstam \& Daniel S. Goldman, The Role of Special Litigation Committees in Shareholder Derivative Litigation, 25 Tort \& Ins L J 864, 879 (1990); Dent, $75 \mathrm{Nw} \mathrm{U} \mathrm{L} \mathrm{Rev} \mathrm{at} \mathrm{97,} \mathrm{129-30} \mathrm{(cited} \mathrm{in} \mathrm{note} \mathrm{10).} \mathrm{For} \mathrm{an} \mathrm{analysis} \mathrm{of} \mathrm{a}$ special type of indirect cost that might be incurred by a public utility simultaneously involved in a rate proceeding, see In re Consumers Power, 132 FRD at 483-86. Moreover, this type of factor usually would support a recommendation that a derivative claim be dismissed regardless of the intrinsic merits of the derivative claim.

(3) The American Law Institute, in evaluating the role of deterrence in a derivative action, would also take into account "whether the legal rule [that] might otherwise result is largely dependent upon private enforcement through proceedings such as the derivative action." ALI Tent Draft No 8 at 146 (cited in this note). Where there are parallel direct and derivative actions being litigated, the need to rely on a derivative action to perform a deterrent role is reduced.

Often, there is also a countervailing consideration. Some courts and commentators have urged that special consideration should be given to a corporation that voluntarily undertakes appropriate corrective or disciplinary measures before or after demand has been made to initiate a derivative action. See Stein v Bailey, 531 F Supp 684 (SD NY 1982); ALI Tent Draft No 8 at 130-31 (cited in this note).

39. See note 6 . 
documentary evidence to justify bringing the case to a jury, or my determination that the possibility of winning the case was "remote."

This standard involved two separate types of analysis. Before concluding that there was insufficient evidence to go to a jury, ${ }^{40}$ the plaintiffs were given the opportunity not only to present relevant documents for my examination, but also to explain their interpretation of the evidence. ${ }^{41}$ For this type of procedure to work, the plaintiffs must have access to all the relevant documents.

The separate determination that the likelihood of a plaintiff winning a case was "remote," in the sense of Financial Accounting Standards Board Statement No. 5 , would only be made if the plaintiffs could clear the summary judgment threshold (that is, present sufficient evidence to go to the jury). A conclusion that success on the merits is remote should be a rare result in those instances when there is disputed testimony likely to go to a jury. Nonetheless, to avoid what in great likelihood will be unnecessary expense, a disinterested person should be permitted to conclude that the plaintiffs' case is so weak that further proceedings could not be justified in the best interests of a corporation. The alternative approach would require a full investigation of claims so weak that the likelihood of success is "slight." To ensure that the disinterested person does not abuse the power to reach this conclusion he or she should be required to file a report with a court explaining, among other points, the basis of each recommendation.

Second, after dispensing with the weakest claims, I conducted a fuller factual and/or legal investigation into the remaining causes of action in Rospatch. The purpose of this investigation was to determine if there was any cause of action for which I believed it likely that the plaintiffs could demonstrate ( 1 ) it was probable that there would be sufficient evidence to go to a jury or other fact finder, and (2) the chances of prevailing before the jury or other fact finder was greater than "remote." If those two criteria were met I believed it would be appropriate to analyze the costs and benefits of further proceeding. Clearly a cost-benefit analysis would be appropriate whenever, to use the language of Financial Accounting Standards Board Statement No. 5, the likelihood was "probable" that a jury or other fact finder would find in favor of the plaintiffs. But even when the likelihood was only "reasonably possible" (less than probable but more than remote) that the jury or other fact finder would find for the plaintiff, an action would still be in the corporation's best interests if the probable benefits (likelihood of success times reasonable estimate of recovery) exceeded the probable direct costs of the litigation to the corporation. For example, if it was concluded that the likelihood of success was only one in three, but a reasonable estimate of the recoverable amount equaled three million dollars, then the expected value of the suit would be one million dollars. The suit should proceed as long as the

40. This procedure is different than summary judgment under FRCP 56.

41. See notes 53-54 and accompanying text. 
probable costs to the corporation were less than the one million dollar amount.

Third, on those causes of action where I concluded that the plaintiffs were likely to present a case sufficient to go to a jury or other fact finder and the likelihood of success was greater than remote, a cost-benefit analysis would normally be appropriate. Here one would need to analyze: Who is likely to be held liable in each cause of action? What is the likelihood that the plaintiff will succeed on each cause of action? What is a reasonable estimate of how much the corporation is likely to recover? What is a reasonable estimate of the direct litigation expenses the corporation would have to bear? Here also the issue of a corporation's indemnification insurance may become particularly relevant both because of the difficulties of collecting damages from individual defendants and because specific types of claims involving intentional misconduct are not insurable. ${ }^{42}$

\section{B. Reasonable Investigation}

The concept of what constitutes a "reasonable investigation" is neither defined in the Michigan statute nor explained in the Reporter's comments. ${ }^{43}$ In the context of judicial review of special litigation committees in derivative actions, a number of court decisions have analyzed what type of investigation would be appropriate. ${ }^{44}$

Generally, judicial authorities require a reasonable investigation recorded in "a thorough written record of the investigation and its findings and recommendations." 45 Commentators have further urged that the report

42. Throughout all of this analysis, a final aspect of the Joy $v$ North standard is relevant. A disinterested person must accept settled law as settled. Judge Winter implied as much when he wrote that it is not the function of a disinterested person to "fashion the appropriate legal principles." 692 F2d 880, 892. Although, in some instances, a disinterested person may have to predict what the court will do when the law is not settled, even this prediction should involve a good faich effort to estimate how a court analogizing from existing precedents is likely to analyze an issue rather than a normative analysis of what the law should be. A disinterested person, or for that matter a special litigation committee, must not lose sight of the fact that he or she, unlike a judge, is unconfirmed and essentially involved in a limited ad hoc procedure.

43. Even given the independence and detachment that a disinterested person can bring to an investigation, three commentators have stated of the Michigan statute:

Whichever group is to make the determination of the best interests of the corporation in a given case, procedures should be adopted, particularly in the case of suits against directors, that will support a finding of good faith and reasonable investigation under the circumstances. The group should conduct an adequate investigation, including the use of outside counsel or experts as appropriate, and it should prepare a written report detailing the reasons for its conclusion. The scope of the investigation will depend upon the nature of the allegations. The full expense and procedural formalities that have grown up around special litigation committee practices are not necessarily required.

Schulman, Moscow \& Lesser, Michigan Corporation Law $\$$ Practice $\$ 4.26$ at 139 (cited in note 5).

44. See for example, Auerbach, 47 NY2d at 634-36; Zapata Corp., 430 A2d at 788-89; Kaplan v Wyatt, 484 A2d 501, 506-09 (Del Ch 1984).

45. Zapata Corp., 430 A2d at 788; compare Kaplan, 484 A2d at 510; In re General Tire E Rubber Co. Securities Litig., 726 F2d 1075, 1085 (6th Cir 1984); Hasan, 729 F2d at 379 (failure to interview individuals who could have provided crucial evidence). 
"should be required to describe with particularity the facts and assumptions underlying each reason for [a] decision to oppose the derivative suit." 46

The investigation will usually involve interviews, which may be recorded in typewritten summaries; ${ }^{47}$ a review of relevant corporate, legal, and accounting documents; 48 and an investigation, when appropriate, of prior work of the corporate audit committee or prior depositions or examination transcripts taken in earlier proceedings. ${ }^{49}$ However, to the extent that there is reliance on earlier work, the courts have required its verification. ${ }^{50}$ In some instances, a special litigation committee also has met with plaintiffs' counsel in the derivative or related actions. ${ }^{51}$

A special litigation committee investigation will not survive judicial review if it is found to be "so restricted in scope, so shallow in execution, or otherwise so pro forma or halfhearted as to constitute a pretext or sham." 52 However, when an investigation is conducted in good faith, the courts have found investigations "reasonable" even when they have criticized aspects of the procedure or scope..$^{53}$

These special litigation committee precedents provide a good starting point for analyzing the appropriate standards in a disinterested person investigation. What is singularly missing from existing precedent, however, is an appreciation of the psychological reality of a special litigation or disinterested person investigation. Unlike a court or an adversarial deposition, the investigation is conducted typically with a single investigator meeting the potential witnesses and their counsel. Many, if not most, witnesses will be defendants or allies of the defendants and whether coached or not, will take pains to appear reasonable.

The investigator typically will spend a considerable period of time interviewing the most significant witnesses. There are none of the conventional devices found in litigation to fortify the investigator's skepticism or, to use perhaps a better phrase, appropriate agnosticism. Unlike a trial or deposition setting, no opposing counsel is present to interpose a hostile

46. Dent, $75 \mathrm{Nw}$ U L Rev at 129 (cited in note 10). Compare Watts v Des Moines Register E Tribune, 525 F Supp 1311, 1328-29 (SD Iowa 1981) ("[P]laintiffs may inquire into what factors entered into the committee's decision, but not why such factors were considered or not considered.").

47. See, for example, Kaplan, 484 A2d at 511, 517; Rasengarten v Buckley, 613 F Supp 1493, 1497. 1501-03 (D Md 1985); Peller, 707 F Supp at 528.

48. See, for example, Auerbach, 47 NY2d at 635; Holmstrom v Coastal Indus., Inc., 645 F Supp 963, 976 (ND Ohio 1984); Rosengarten, 613 F Supp at 1495, 1503.

49. See, for example, Awerbach, 47 NY2d at 635; American Law Institute, Principles of Corporate Governance: Analysis and Recommendations $\$ 7.10$ at 36 (Tent Draft No 9, April 14, 1989).

50. See Stein, 531 F Supp at 687, 694; Peller, 707 F Supp at 529; compare Genzer, 498 F Supp at 696.

51. See Maldonado v Flynn, 485 F Supp 274, 284 (SD NY 1980), modified, 671 F2d 729 (2d Cir 1982); compare Abbey $v$ Control Data Corp., 603 F2d 724, 727 (8th Cir 1979) (plaintiff declined an invitation to meet with a special litigation committee).

52. Auerbach, 47 NY2d at 634; Stein, 531 F Supp at 695.

53. See, for example, Kaplan, $484 \mathrm{A2d}$ at 518-20; Rosengarten $v$ International Tel. E Tel., $466 \mathrm{~F}$ Supp 817, 825-26 (SD NY 1979) (omission did not cast serious doubt on overall thoroughness of investigation). 
cross-examination or a timely objection. The investigator, when witnesses are not under oath, has no real ability effectively to remind a witness of the penalties for perjury. While an investigator can reach conclusions about the likelihood that a witness will appear persuasive to a jury or other fact finder, this type of conclusion arguably has little place in a final report. In sum, the very nature of the proceeding is biased in favor of not finding fault or of minimizing fault.

Here, too, the German model of civil procedure is different. At one stage, counsel for both parties may be present at the interrogation of each witness, may suggest questions to the judge, or, after the judge has completed an interrogation, may pose additional questions. ${ }^{54}$

These conventions would probably be regarded as inconsistent with the informality and streamlining of discovery sought to be achieved through the disinterested person procedure. Alternatively there are certain mechanical steps that could be taken to minimize the bias in the disinterested person process, but each of them involves tradeoffs. For example, there may well be advantages to having the witnesses sworn in and testimony recorded by a court stenographer. This step, however, should not be taken lightly. The informality of the disinterested person procedure has the advantage of eliminating virtually all objections from counsel to lines of questioning. This may dramatically streamline the time involved in discovery and stimulate witnesses to speak more candidly than they would on a record.

It seemed preferable to me in attempting to create an evenhanded disinterested person process to integrate the most desirable aspects of an adversarial process into the disinterested person's investigation. In the Rospatch investigation this was facilitated by the fact that virtually all relevant documents were stored in a document depository. ${ }^{55}$ This meant that I could direct the plaintiffs to submit to me all documents that they believed tended to support the positions advocated in their complaint with memoranda explaining the significance of the documents produced.

After I had reviewed all of the plaintiffs' document submissions and other documents that I received from Rospatch, I circulated to the parties a statement specifying the issues that I believed did and those that did not justify further investigation. After that statement was circulated, the defendants were given the opportunity to forward for my review all documents that they believed supported their positions with memoranda explaining the significance of the documents they produced.

I took several steps to ensure that I did not merely receive relevant documents but understood them. First, as mentioned, to assist me in evaluating the documents provided by the parties, I offered both the plaintiffs

54. Langbein, 52 U Chi L Rev at 824, 828 (cited in note 3). Compare Benjamin Kaplan, Arthur T. von Mehren \& Rudolf Schaefer, Phases of German Civil Procedure I, 71 Harv L Rev 1193, 1199-1202, 1208-10, 1232-37 (1958).

55. See In re Rospatch Securities Litigation, et al, Nos 1:90-CV-805, 1:90-CV-806, 1:90-CV-807, 1:91-CV-085, slip op at 9 (WD Mich March 14, 1991), 1991 US Dist LEXIS $3270 * 9$ (Greeley). 
and the defendants the opportunity to attach memoranda explaining the documents' significance. Second, I selected a consultant on accounting standards and the analysis of accounting work papers. Third, I took other steps to ensure that I received a critical analysis of the relevant accounting and auditing issues. For example, I interviewed the plaintiffs in related direct litigation. Each of these individuals was an accountant who provided me with an adversarial analysis of relevant accounting and auditing issues. I also interviewed certain of the plaintiffs' potential fact witnesses and stated my willingness to receive affidavits from potential expert witnesses for either side. Fourth, on several occasions I requested that the parties file briefs addressing specific questions concerning the relevant legal and accounting standards to be applied in this case.

These procedures replicated some of the adversarial presentations likely to occur at trial, and through them I was able largely to allay the legitimate concerns of both plaintiffs and defendants that I would not discover all that I should or that I would not understand what I discovered.

It has not always been the case that plaintiffs have had the same access to documents as the plaintiffs did in the Rospatch derivative action. I believe it often would be preferable if they have such access. Only when plaintiffs' counsel critically reviews the relevant corporate and accounting documents can a court be confident that a fair process has occurred. The court can also then fairly impose a burden of production on plaintiffs similar to that appropriate at trial. ${ }^{56}$

To be sure, document production can be expensive. But there are better ways in a fair process to limit expense than by cutting off a plaintiff from document production. First, the court can issue a stay, preventing the parties from conducting depositions. Properly armed with both plaintiffs' and defendants' documents and explanatory memoranda, this is an appropriate role of a disinterested person.

Moreover, a key advantage of the disinterested person procedure is that, to a greater extent than the special litigation committee, it can limit the number of interviews and the amount of document production when and if it becomes clear that the plaintiff's case is essentially nonmeritorious. Because the disinterested person begins as a neutral fact finder, his or her judgment should be entitled to greater weight in reaching this conclusion than that of a special litigation committee.

Even when the plaintiff has filed a meritorious claim, economies can be achieved because of the disinterested person's control over discovery. For example, the most challenging aspect of the Rospatch investigation was effectively to distinguish those claims which, after review of documentary evidence and explanatory memoranda, I did not believe warranted further investigation from those issues where further investigation was warranted. Unlike a court, which has well-recognized opportunities to dismiss claims

56. See, for example, Edward W. Cleary, et al, McCormick on Evidence $\S 336-38$ (West, 1984). 
through motions practice before a full trial on the merits, a disinterested person or special litigation committee has no recognized intermediate process in its investigation. Yet the Rospatch derivative case began with a complaint that asserted twenty-two different causes of action that varied widely in their persuasiveness. I was additionally concerned that without some device to focus the attention of the parties on the issues where further investigation was warranted, additional document production by both sides would be clumsy and ill-focused, and persons that I sought to interview would have little guidance in how to prepare appropriately. Finally, I was aware that any party challenging the recommendations of the disinterested person report would have a substantial burden of persuasion. ${ }^{57}$ As a matter of fairness I sought to ensure that all parties were offered every reasonable opportunity to bring to my attention relevant documents or arguments before I filed my final report.

The primary device I employed to narrow the issues and focus the investigation was a Summary of the Documentary Evidence Reviewed to Date by the Disinterested Person. ${ }^{58}$ The Summary was prepared after an extensive period of document review but before any interviews had been conducted. ${ }^{59}$

The Summary itself contained two parts. Part I identified the issues that required further investigation. This Part essentially summarized or quoted the documentary evidence available to me by that date and highlighted areas where legal briefs would be requested or factual investigation would be necessary. On a few issues I announced that I would request only legal briefs since the relevant facts did not appear to be in dispute but the applicable law was uncertain. The purpose of Part $I$, in essence, was to narrow the focus of the investigation to those issues where there was a reasonable basis to believe that the plaintiffs might have alleged a complaint sufficient to go to a jury and the likelihood was greater than remote that the plaintiffs would prevail. This narrowing occurred both in the sense of focusing the investigation on a shorter list of issues, and, equally significantly, by focusing the factual investigation on a specific time period.

Part II of the Summary outlined the issues that I believed could be resolved without a full investigation. I intended this Part to be written in similar detail as the final report. The plaintiffs were given the opportunity to persuade me that $I$ had reached an incorrect conclusion concerning these issues when I met with plaintiffs' counsel after distribution of the Summary.

At meetings with plaintiffs' and defense counsel, I discussed with the parties a list of persons I believed appropriate to interview on the issues that

57. See notes 52 and 53 and accompanying text.

58. Compare the preliminary report procedure employed by the Examiner, In re Revco, D.S. et al, Nos 588-1305, 588-1308 through 588-1321, 588-1761 through 588-1812, and 588-1820 (Bankr ND Ohio Prelim Rep, July 16, 1990; Final Rep, Dec 17, 1990).

59. The Summary was accompanied by a cover letter which stressed: "This document tentatively states my conclusions as to which issues require further investigation in the Rospatch derivative action and which do not. These are only preliminary conclusions." Letter to Jill S. Abrams, David D. Joswick \& Jon G. March, from Joel Seligman, May 9, 1991. 
then appeared to warrant further investigation. As my review of documents and conduct of interviews proceeded, I added additional individuals.

The interviews were conducted employing "informal" procedures and were not transcribed or tape recorded. Handwritten notes were made and, after most interviews, I dictated into a tape recorder interview notes that were subsequently typed. To ensure the accuracy of these notes, the parties and I had agreed initially to a procedure under which I would circulate my notes to the person interviewed to provide an opportunity for correction or amplification. After Rospatch's counsel objected that this procedure might jeopardize Rospatch's ability to claim that the notes were privileged or confidential, I adopted an alternative procedure. I did not circulate my notes to any person interviewed for correction or amplification. Instead, when I intended to rely on the notes and I believed the point on which I would rely could reasonably give rise to controversy, I either re-interviewed the person on that specific point or requested an affidavit. In retrospect, the affidavit procedure proved particularly useful in preparing the final report.

Certain interviews were conducted by telephone. These typically were interviews on specific and quite narrow points or were corroborative "reinterviews" related to earlier investigations where a signed and sworn affidavit had been produced.

I interviewed each defendant in person. In each interview with a defendant I articulated the evidence I had found that was likely to be presented by the plaintiffs at a trial to attempt to demonstrate the liability of that particular defendant. My purpose was to understand the likely defense each defendant would offer. I tried to reduce the possibility that the defendants might be more effective at trial after interrogation and deposition in my investigation by offering to receive a further written affidavit or statement from each defendant on each issue where I believed it was reasonably possible that a jury or other fact finder would find liability. In "confronting" each defendant, I did not use an adversarial tone. I viewed my role as that of a fact finder, not an advocate conducting a hostile crossexamination. At the same time, I articulated to each defendant in considerable detail the exact bases for possible culpability. I was insistent in probing for responses and, on occasion, told defendants that I did not believe that a jury would be persuaded by a response. I wanted to know if the defendant could offer a more persuasive response or if I had heard the best that was likely to be offered.

Before I filed my final report I urged the parties and the Rospatch litigation committee to settle four specific issues. In two instances I indicated to the defendants that I had not reached legal conclusions concerning specific issues but as a preliminary matter I thought there was some likelihood that the defendants might lose these issues. This prompted Rospatch and various defendants to "unfund" an indemnification trust and to resubmit to shareholders two supermajority provisions where there was a question of whether a sufficient vote had initially been cast to adopt the provisions. On 
two other issues I suggested to individual defendants and Rospatch that there was a significant likelihood that I would conclude that it was probable that the individuals had violated the relevant law. Given all of the facts involved, I stated that I would recommend to the court a settlement by which these individual defendants would return to the court all indemnification advances received to date and Rospatch would agree not to bring a derivative claim. In performing this role in the settlement process, I made it a point to state all conclusions to both sides. If I recommended a settlement to a defendant, I explained the recommendation and the reasons for it to the plaintiffs. At the same time I did not participate in settlement negotiations. I simply stated to the parties that I would support certain settlements but I left it to the parties to negotiate them. ${ }^{60}$

\section{IV}

\section{Conclusion}

The procedures employed in the Rospatch derivative litigation were responsive to the circumstances that the court and I faced in that case. These procedures may not be fully appropriate in other contexts.

The advantage of the disinterested person approach is that it provides the judiciary a new alternative in resolution of shareholder derivative litigation. Unlike the special litigation committee that, in my opinion, has been criticized appropriately for its overwhelming tendency to favor defendants, the disinterested person procedure offers the legislature or judiciary an opportunity to employ a more neutral approach while at the same time preserving the advantages of reduced cost and disruption associated with the special litigation committee approach. In relatively smaller corporations, the disinterested person may also be viewed as a "bargain" compared to the special litigation committee. When the disinterested person is a lawyer, he or she does not need to hire separate counsel and can perform a role trying to help inspire settlements that would be more difficult for counsel to a special litigation committee to perform.

Nonetheless the most significant potential use of a disinterested person probably will be in applying the law to complex facts. Here the disinterested

60. The parties were able to negotiate successfully the four specific issues but not an overall settlement. I had hoped that my distribution of the documentary Summary would prompt an overall settlement. In this instance it did not.

The filing of the final report prompted discussion of a number of questions I will leave to others in the bench and bar, such as: Should the report be a public filing in a litigation process or subject to limitations on its distribution? Should the report, if adopted, have collateral estoppel effect in related direct proceedings? If not, should the report have evidentiary value? As a general matter, the simultaneous litigation of direct and derivative lawsuits raises a host of complex problems. It should also be noted, however, that, as stated, a direct lawsuit can reduce the need for a derivative claim to perform a deterrent function and, at least in Rospatch, the existence of the direct claim significantly simplified the role of the disinterested person by causing virtually all relevant documents to be directly produced to the plaintiffs. This meant that the derivative lawsuit plaintiff, not the disinterested person, read through close to 300,000 pages of documents to separate the wheat from the chaff. 
person can perform a useful "triage" role, distinguishing meritorious from nonmeritorious claims and sharpening the understanding of the court and parties with respect to the facts concerning meritorious claims. In contrast, cases involving simpler fact patterns will have less need for a disinterested fact finder. Chancellor Brown's complaint that the special litigation committee procedure essentially sets up "a form of litigation within litigation" is equally applicable to the disinterested person procedure. ${ }^{61}$ If there is a need for either alternative approach, the need will be generally limited to complex cases where a protracted investigation is warranted.

With complex cases, a significant issue suggested by Rospatch is whether the appointment of a disinterested person should be solely on a motion from the corporation or whether it also might be made by the court on its own initiative. Since the corporation will normally bear the cost of hiring the disinterested person, there is a principled basis for limiting the person's appointment to those cases in which the corporation desires it. On the other hand, the court will usually have a quite realistic sense of when this type of procedure may simplify fact finding and conceivably inspire settlements.

On balance I believe the disinterested person model worked well in Rospatch. However, the area in which it seemed to be most in need of improvement was the role of the disinterested person in helping inspire settlements. One advantage the German model may have over the disinterested person procedure is that the presence of counsel at each witness interview may make a German judge's evaluation of likely outcomes seem more credible than the opinions of the disinterested person. The disadvantage of having counsel of both sides present at the interviews might be felt in terms of a lesser willingness of witnesses to speak candidly and fully.

There are other factors that may militate against the disinterested person being as effective as a German investigative judge in inspiring settlements. In Rospatch, these factors included the use of informal procedures and the fact that the judge, not the disinterested person, ultimately issued opinions. It may well be that the disinterested person will be more effective in helping inspire settlements only when he or she is joined by the judge in settlement or other periodic conferences. Like much else in a procedure only employed once to date, this is an area where a certain amount of trial and error will be appropriate. 


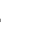

